\title{
Traditional Songs of İlorin: Enacting Identities, History, and Cultural Memories
}

\author{
Hakeem Olawale \\ Kwara State University, Nigeria \\ hakeem.olawale@kwasu.edu.ng \\ hakeemolawale4@gmail.com
}

\begin{abstract}
İlorin is a distinct community and a melting pot where people of diverse ethnic and cultural identities came together to form a settlement in the $17^{\text {th }}$ century. These ethnic groups include Yorùbá, Haúsá, Fúlàní, Núpé, Kànnìké, Kéńbérí, Bàrùbá, and Malians, Arabs, among others. However, despite these ethnic and cultural diversities of İlọin and the Fúlàní political hold on it, Yorùbá language is the lingua franca of the community. How these ethnic groups find their voices and articulate their historical and cultural identities within this unified framework becomes a source of concern. As a response to this concern, traditional songs of İlọrin like dàdàkúàdà, bàlúù, agbè, wákà, kèngbè, orin ọlọmọ-ọba İlọrin, among others sung in Yorùbá language become a site of contestation of ethnic and cultural identities. The focus of this essay is to analyze İlọin traditional songs as they portray and contest ethnic identities, reconstruct history, and revitalize cultural memories of indigenes. The paper argues that given such a diverse ethnic and cultural origins, performance of Îlọin traditional songs become a reminder of family histories, origins, political structure, hegemonic influences, myths, legends, Islamization of İlọrin, and a way of ensuring harmony and bridging generational gaps among the various groups in a state that is known as the "State of Harmony".

\section{Introduction}

It has been pointed out that oral artists are part of the custodians of cultural heritage due to their rich knowledge about their communities which they transform into songs. These songs are usually embedded with the themes
\end{abstract}


of what has happened in the past, the present happenings, and possible legacies that will enhance peaceful co-existence of the future generations. This paper, therefore, uses İlọrin Yorùbá traditional songs as a medium to mirror the historical reconstruction of different family's ancestral origin. İlọrin is a multi-ethnic community comprising of many tribes that successfully came together to form a distinct community that has adopted Yorùbá as its lingua franca. The memory and remembrance through the traditional song plays prominent roles for different families whose fore-fathers left their ancestral homes decades and centuries ago to trace their original ancestral origin. It even allows some families to re-unite.

Some foreign scholars had erroneously denounced African unwritten literature using the lenses of the Western written literature as the yardstick for all forms of literature. These scholars argue that anything unwritten cannot be regarded as literature. But this is totally untrue because there is cultural differentiation which arises from relativity in the sensorium of different cultures. Therefore, either oral or written, the function of literature as the channel that mirrors the society is of paramount importance to every society that has it (Ajíbádé, 2012: 30-31). This paper, which utilises İlọrin traditional songs as one of the oral genres that are prominent in African society is an approach to prove that traditional music through the rendition by the oral artists serves as tools for rememberance, fact findings, memory, and historical reconstructions. As Finnegan (1992) opined, “...interests in the oral tradition and verbal art is to understand people's cultural activities and artistries..." (25). What this implies is that many facts are richly embedded in oral traditions which serve as mirror of the society. In a nutshell, the oral traditional singers are like contemporary computer memory cards that stored information in their memory that could be explored for different purposes whenever needed. It has also been noted that oral tradition is the vast field of knowledge through which cultural information and messages are transmitted verbally from one generation to another. It is the complex corpus of verbal arts created as a means of recalling the past. Sometimes oral tradition is used interchangeably with folklore or elements such as language and belief systems that are shared by a group; what gives a community its cultural and national identity. In contemporary usage, oral tradition or folklore means popular and group-oriented expressions of culture (Akínyẹmí, 2011).

The opinions of Ajíbádé, Finnegan, and Akínyẹmi above center on the power of orality in any given society to remember the past and to update their memory. In a similar vein, Okafor (2005) maintains that,

Through song texts, a person learned the moral codes of his land, its chronology and history, and the guiding principles and ethics of his land. 
He also learned about his own language, the things his people lives by, and how the society worked. All these were learned through music that ranged from folk tunes to highly specialised ritual music, including chants, incantations and minstrelsy (209).

The above opinion of Okafor also implies that oral literature mirrors society it focuses on and that it is useful in the maintenance of such society.

The analysis of our data in this paper hinges on sociological approach and diffusion theory. According to Barber (1979), "Sociology is a way of trying to understand society, its structure, how it works, and the forces that bring about changes in it" (1). This is in tandem with Ògúnsínà (1987) who portends that, "Literature is concerned with men and his society. It is an art composed of words in such a way that it proffers entertainment, enlightenment, and relaxation. It attempts to develop, elevate, expand, and transform the experience of its audience" (19). Our main argument is that sociology of literature proves that there is nothing in a particular work of art that is outside the society.

Likewise, it is the contention of diffusion theorists that history, migration, and culture are products of society and that probably, cultures have a particular origin before dispersal to various societies. The argument is that culture is a product of society and that it lends itself to diffusion, adaptation, and variation.

\section{Identity and Creation of History}

Ilorin is the capital of Kwara State in Nigeria. It is about 300 kilometers to Lagos, the economic capital of Nigeria and about 500 kilometers to Àbújá, the political capital. İlorin was founded in the 17th century (Salihu \& Jawondo, 2006:1). Though there are multifarious themes embedded in different kinds of İlorin songs, the main focus of this paper is how the artists make use of their songs in the creation of social history and identity.

Music plays prominent roles for some family members to know and trace their ancestry despite some diffusions of languages and cultures. For example, Jimoh (1994) argues that,

...the core families in Àgbajì namely Ilé Sáúrà, Ilé Àbùro, Ilé Bàbá Sàárẹ, Ilé Àgòrò and Ilé Imam Àgbajì were originally Sudanese Arabs from a town called Ar-Baji on the Blue Nile...Members of Ibrahim Bàtúrè family at Òkè Apòmù are Arabs by origin. They migrated to İlọrin from Agades in Niger Republic. The Òjíbárá family in the same area are of Fúlàní descent... The Șolágbẹrú family at Àgbajì, the Ọnágun family of İta-Ẹgbá, the 
members of Ilé-Olóyin (formerly called Ilé-Igbộn) at İta-Elẹppà, the Gíwá family of Pópó Gíwá, and the Mèkábárà family of İta-Ògúnbọ́ are Kànúrì migrants. Sọ́lágbẹrú migrated from Bama in Bornu and was founder of ancient Òkèsúnà...The family of Magaji Kúǹtú are Boko-Barubas paternally but Fulani maternally while members of Ilé Elẹ́ran, Àdáńgbá are Barubas... Members of the following families are Hausa by ancestry: Ilé Alálikínlá at İta Ògúnbọ́, Ilé Shírù at Ôde Alfa Nda, Ilé Saba’ani at Òde Aláúsá and Ilé Saba’ani at İdí-Òrombó, Ilé Jáwòǹdó at İta Ògúnbọ́ and Ilé Alfa Ajọngộlọ̣ which was formerly called Ilé Alápatà... (10-11).

The above excerpt reveals that many families in İlorin are confined and interwoven. But despite their different background, songs are used as the tool for self-identity and remembrance of the past and update of memory. For instance, the excerpt of agbè song (gourd rattle) of Káríkáná and Núúrù Àjàdí Kúrè of İlọrin below, recorded on 15 February, 2015, reveals that eleven Emirs have been enthroned in İlọrin.

Àwọn baba n'lá wa ló mórin agbè,

Délùu İlọin, lọjộ tó ti pẹ ni.

İpele eleẹéekeje làwá jẹ

Ninú olórin agbè nílùu İlọin.

Lát'Ọyọ Ilé,

Wọ́n ti ñ jọba nílùu İlọin ọjọ pẹ́.

Oba bii mọ́kànlá ló ti jẹ.

Elẹẹkínní jẹ, ikeji je.

Elẹẹkẹta jẹ, ikẹin jẹ.

Títí tó wée dérí mộkànlá tó kan Súlú.

Súlú Kàrináánì Gàmbàrí lọba kẹsàn-án ní İlọin.

Okùnrin mẹẹẹdoọgbọnn.

Oba tíi pọba ránnsé ni Súlú ọba wa.

Oba Alárisisikí tó lówó lộwọ́, ọ láyà;

Ó ní tírà, ó lóògùn.

İgbà tó dẹleẹẹkẹwàa lọba kan Àlíu Baba Àgbà.

İbùràimọ ọmo Súlú Gàmbàrí

$N$ lọba kọkànlá n'Lọin wa,

Tín be lérí ọa

(Our forefathers brought agbè music

Into İlọin long time ago.

We are the seventh generation

Among agbè artistes in İlọin 
That came from Ọyọ́-Ilé.

There have been kings in İlọrin long time ago.

Eleven kings has been installed so far.

First king, second king.

Third king, fourth king installed.

Until Súlú the eleventh king.

Súlú Gàmbàrí was the ninth Emir of Ìlọrin.

A very powerful man.

A king that send other kings on an errand.

Rich king, brave king.

He had different metaphysical powers.

Bàbá-Àgbà was the tenth Emir;

İbùràimọ, the son of Gàmbàrí.

The eleventh Emir

Is the one on the throne).

The excerpt reveals that the singers are the seventh generation of agbe singers/performers in İlọrin, and that their forefathers migrated to İlọrin from Oyọ́-Ilé. The singers claims further that the ninth emir, who is the father of the incumbent Emir of İlọin, was very powerful metaphysically, brave, and rich. Mention was also made of Àlíù Bàbá Àgbà who was the 10th Emir of İlọrin.

In another excerpt fron the bẹ̀nbẹ/àlugétà song of Àlàájì Ismaila Àtàndá, the prowess and characteristics of one of the prominent tribes in İlorin is revealed. Their forefathers were known to be brave in war front because they don't condone unnecessary rivaly. They resemble themselves in character and they also have significant tribal mark of identification wherever you see them. These are encapsulated in the song below:

Gòbírí rorò, éé ijà roro

Gòbírí rorò, ée ijà rorò

Gògòbirí o nií jọgọ

Taa ló ní ọé wọn?

Gògòbirí o nií jọgọ̀

Taa ló ní ọé wọn?

Àgékù ejò

Gògòbirí, oro lè é șe

Tó bá dijà tán

Gòbírí ni e pè sí wọn

Gòbirí jọraa wọn 
Wọ́n tún fiwà jọraa wọn

Gòbirí jọaa wọn

Wọ́n tún fiwà jọraa wọn

(Gògòbírí are wicked, wicked fighters

Gògòbírí are wicked, wicked fighters

Gògòbírí dont take nonsense

Who asked you to marry them?

Gògòbírí dont take nonsense

Who asked you to marry them?

You are like a wounded snake

Gògòbírí you are so wicked

When it comes to fighting

Invite Gògòbírí to tackle them

Gògòbírí resembles themselves

They resemble one another in character

Gògòbírií resembles one another

They resemble one another in character)

In the excerpt of Àrẹmú Òsé dàdàkúàdà song from his record tagged "Àrẹmú Gbàwọọ dù", the historical identity and the relationship of the present Emir of Îlorin with the past emirs were revealed as seen in the song below.

Ilé iyá rẹe, ilé ọba İlorin ni

Ilé baba rẹ̀, ilé ọba İlọin ni

Àlíu Baba Àgbà,

Ėgbọ́n mọmoọ rẹ ni,

Ọ jọba İlọin.

Àbùdùkáádíri,

Baba mọmoọ rè ni,

Ó jọba İlorin.

Báwà tó bí Káádi,

Baba-baba mọmoọ rẹ ni,

Ó jọba İlorin.

Súlú baba rẹ,

Ó jọba İlorin.

Báwà tó bí Láọfẹ́,

Baba-baba re ni,

Ó jọba İlorin,

Ọ wáá terí i Lọoọyà, 
O bọ́ sérí Adájộ.

O torí Adájó,

O bọ sérí ọba.

Aséèjoyè ọmọ Súlú, ọmọ Bọlánítà.

(Your mother is from the royal family

Your father is also from the royal family

Àlíù Baba Àgbà

Is your mother's uncle

He became the king in İlọrin

Àbùdùkáádírì

Is your grandfather

He became the king in İlọin

Báwà, the father of Káádì

Is your maternal great grand-father

He became the king in Îlọrin

Súlú, your father

He was an Emir of İlọin

Báwà, the father of Láôẹe

Is your grandfather

He became the king in İlọin

You graduated as a Lawyer

To a Chief Judge

From Chief Judge

You become the king in İlọin

Àséèjoyè, son of Súlú, son of Bọ́láńtà)

The above song excerpt of Àrẹmú Òsé explains a lot about the detailed relationship of the Emir of İlorin and his progenitors. It was pointed out in the song that he, the incumbent king is a bonafide royal family member and would be successful on the throne. According to the opening lines of the song, both his paternal and maternal families are entitled to the throne of İlorin emirship. Furthermore, his mother's uncle, his grandfather, his great grandfather and his biological father who were past Emirs of İlorin were mentioned as authentic members of the royal house who had access to the throne of İlorin when they were alive. With all these multifarious facts that are embedded in the traditional music, it can be clearly seen that in any society, oral literature can never be over-emphasized because it mirrors the society and it is very useful in identity creation and reconstruction of social history.

From the above excerpt, element of cultural and linguistic diffusion are discernible. The title of community leader among the Yorùbá people is ọba 
while the Fúlàní equivalent title is the emir. Although the king is a Fúlàní man but the title used by the musician is that of Yorùbá, in the Yorùbá language. The singer did not use emir because of the Fulani's language that has diffused into the Yorùbá language. Therefore, the Yorùbá perception of king is used.

In a similar vein, the chronological ascension of the past Emirs of İlorin is mentioned in one song of Jólómiró Àlàbí specifically tagged "İtàn Ọba İlọrin" in which he highlights the period of individual emirs on the throne. It is very informative. The song goes thus:

E sún mọ́ yín-ín

E gbộtàn àwọn ọba İlọrin tí wọ́n ti jẹ

Abùdùsàlámi lọ kọ́ joyè n’Îloorin

Ninú ọba tó ti je

1831 lọ joyè n’ílorin

1842 lọ padà lọ wàjà.

Odún mọ́kànlá lọba yẹn lò

Tée jáde láyé.

Téléèbó ni pè ní İlẹbin yiàsi

Șítà ló tún tẹlé e

Ninú ọba tó tún je

1842 ló joyè n'Ílorin

1860 lọ padà lọ wàjà

Odún méjidínlógún lọba yẹn lò

Téléébó ń pè ni eetín yiàsi

İgbà tí Sítà wá kú tán, Odún ộún lọ wá kan ọba Sùbáirù

1860 ló joyè n'ílorin.

1868 lọ padà lọ wàjà

Odún méjọ péré lọba yẹn lò.

Téléébó n pè ní éèti yíasi

E má je o bàjé o o

Kò báje tẹlẹtélè o o

Àliù ló tún tẹlée

Ninú ọba tó tún je

1868 ló joyè n'Ílorin

1891 lộ padà, lọ́ wàjà

Odún mẹtàlélógún lọba yẹn lò

Téléèbó ń pè ní tuẹnti-tírí yiàsi

Odún tó kú ni Mọ́mọ́ wá jọba

1891 ni Mọ́mọ́ joyè n'Ílọin 
1896 lọ padà lọ wàjà

Odún márùn-ún péré lọba yẹn lò

Téléèbó n' pè ní fáifù yiàsi

Ọ wá ku Súlè ọmo ọba İlorin tọ lọ

Kàu Àlàbí ti ń be lọjà tí ń tàwo wa

Kàú Àlàbí 'mọ Súlè, 'mọ Wòrú.

1896 ló joyè n'Ílợin

1915 lọ padà lọ wàjà

Odún mọ́kàndínlógún lọba yẹn lò

Téléébó ń pè ní naintín yiàsi

Sạíbù ló tún tẹlé e

Nínú ọba tó tún je

1915 ló joyè n'ìlọrin

1919 lọ padà lọ wàjà

Odún mẹ́rin péré lọba yẹn lò.

Téléèbó ńpè ni fợọ yiàsi

Sàibù wá kú tán

Ló kan Káádi ọba İlọrin

Agẹmo Adáké-má-fọùn ọmo Labówó.

Àtàndá Òpó baba Dáódù Bààlà.

1919 n lọ joyè ńílorin

1959 ń lọ padà lọ wàjà

Ogóji odún lọba yan lò.

Téléèbó ń pè ni fọ̣ọti yiàsi

E má je o bàjé o o

Kò báje tẹ́lẹtẹ́lè o o

Odún tí Káàdi kú

Ni Súlú jọba...

(Come over here

Listen to the history of the past kings of İlorin

Abdulsalam was the first emir

Among the past kings of İlọrin

He was installed in 1831

He died in 1842

He spent eleven years on the throne

Before his death

Which means eleven years in English

Sítà was installed after him

Among the past kings of İlọrin

He was installed in 1842 
He eventually died in 1860

This king spent eighteen years on the throne

Which means eighteen years in English

After the demise of Șítà

It was the turn of king Sùbáírù that same year

He was installed in 1860

He eventually died in 1868

He spent only eight years

Which means eight years in English

Don't destroy the tradition

Tradition should be protected

Àlíu followed him

Among the past kings of İlọin

He was installed in 1868

He eventually died in 1891

He spent twenty-three years on the throne

Which means twenty-three years in English

The year he died, Mọmọ́ was installed

Mọmọo was installed in 1891

And he died in 1896

He spent five years

Which means five years in English

Then came Súlè, the prince of the departed Ìlọrin king

The father of Àlàbí who sells our musical record at the market

The father of Àlàbí, offspring of Súlè and Wòrú

He was installed in 1896

He eventually died in 1915

He spent nineteen years on the throne

Which means nineteen years in English

Sàíbù followed him

Among the past kings

He was installed in 1915

He eventually died in 1919

He spent only four years

Which means four years in English

After the death of Sàíbù

Then was Káádì, the İlọrin king

Agẹmọ the cool-headed one, son of Labówó

Àtàndá of the Òpó lineage, father of Dáódù Bààlà

He was installed in 1919 in İlọrin

He eventually died in 1959 
That king spent forty years

Which means forty years

Don't destroy the tradition

Tradition should be protected

The year Káádì died

Then Súlú was installed)

This long Pàkenke song of Jólómiró Àlàbí cited nine kings of Ìlọrin in chronological order. As at the time he released his music album, Emir Súlú Gàmbàrí, the father of the incumbent eleventh emir was on the throne. The song is also informative as the singer mentioned the years of installation, years spent on the throne, and the year of death of each emir. The information provided by the artist is highly useful in the construction of the social history of İlorin emirship. This shows that traditional songs can surely be regarded as one of the authentic sources of information and archive of the society. The musicians are part of the society, and they compose their life experiences and observations into songs for the benefit of the populace.

Like his colleague, Àrẹmú Òsé, the singer of the above long excerpt did not refer to the king as emirs but he referred to them as oba. Besides, he portrayed element of linguistic diffusion beyond Fúlàní/Yorùbá divides, he also manifested element of understanding of English as the language of the colonial masters and the lingua franca for Nigeria. In the conclusion of Jólómiró Àlàbí's song, he added to the historiography of the kings of Îlọrin that the incumbent king/emir should endeavor to emulate the identities and personalities of the past kings in maintaining peace and stability of the community. He used the theme of identity consciously to create a visual self-examination of the past, present, and the future to project anticipated expectations of the masses.

As said earlier that the İlorin folksingers use their songs to reveal the identity of people, especially the kings/emirs. An example of such is seen in àlùgétà/bẹǹbẹ songs by Alhaji Ismaila Àtàndá in which Sulu Gambari, a past Emir of İlọin is praised.

Húkùhúkù déo

Gàmbàrí déo

Húkùhúkù déo

Gàmbàrí dé o

Arógúnmásàá déo

Gàmbàrí dé o

Arógúnmásàá déo

Gàmbàrí déo 
Arógúnmásá dé bii tii dé

Gàmbàrí dé bií tií dé

Arógúnmásá baba àwa o

Gàmbàrí baba àwa o

Aríbíkọlá o, ogun la ó lo

Aríbíkọlá o, ogun la ó lọ

Ogun nisẹ́ wa o

Ogun lowó wa a

Ogun nișé wa o

Ogun lòwò o wa a

(Húkùhúkù has come

Gàmbàrí has come

Húkùhúkù has come

Gàmbàrí has come

The-one-who-never-run-away-from-war has come

Gàmbàrí has come

The-one-who-never-run-away-from-war has come

Gàmbàrí has come

The-one-who-never-run-away-from-war has come as usual

Gàmbàrí has come as usual

The-one-who-never-run-away-from-war has come,our father

Gàmbàrí, our father

Aríbíkọ́lá, we will go to war

Aríbíkọ́lá, we will go to war

War is our job

War is our business

War is our job

War is our business)

In the above example, we can see how the artist metaphorically represents his thought and emotion expressively to create a conceptual visual representation of the king/emir. He presents him as the one "one-who-never-run-awayfrom-war". This shows that the king was a dexterous warrior; who was capable of leading the community successfully.

In another example below drawn from Àrẹmú Òsé dàdàkúàdà traditional song of İlorin, both past and pressent emirs are listed. The singer referred to the kings as oba instead of emir and made mention of their ancestral origin which is Sókótó. This is also an indication that traditional singers of any society are like archive of knowledge with multifarious historical facts.

Àbùdùsàláámì, Șítà, 
Sùbéérù, Àlíyù

Mọmoó, Súlè

Báwà, Àbùdùkáádíri,

Súlú, Àlíu Baba Àgbà

Bùrẹẹemọ Kọ́lápọ

Oba di mọkànlá n'Ílorin tọ́ jẹ

Bùràimọ ọba ò

Oba ò, ọba ò̀

Bàágbà ọba o

Oba ò oba o o

Súlú ọba ò

Oba ò ọba o o

Àbùdùkáádíri ọba o

Oba ò oba o o

Báwà, ọba o

Oba ò ọba o o

Oba Súlè, ọba o

Oba ò ọba o o

Oba Mọ́mọ́, ọba o

Oba ò oba oo

Ọba Àlíu, ọba o

Oba ò ọba o o

Oba Sùbéérù ọba o

Oba ò, ọba o o

Ọba Sítà, ọba o

Oba o, oba o o

Àbùdù Sàláámì, ọba o

Oba o, oba o o

İsọlá 'Mọ Álími

Fúláni Sóokótó

İsọ̣lá 'mọ Àlími

Fúlání Sóokótó ó ó ó.

(Abdul-Salaam, Șítà

Zubair, Aliyù

Mọ́ma, Súlè,

Bawa, Abdul-Kadri

Zulu, Alíu Baba Àgbà

Ibraheem Kọ́lápọ

Eleven kings have been installed in İlọin

İbrahim, the King 
The king, the king

Bàágbà, the king

The king, the king

Súlú. the king

The king, the king

Abdul-Kadri, the king

The king, the king

Báwà, the king

The king, the king

King Súlè, the king

The king, the king

King Mọmọ́, the king

The king ,the king

King Àlíù, the king

The king, the king

King Zubair, the king

The king, the king

King Sítà, the king

The king, the king

Abdul-Salaam, the king

The king, the king

İsọ̣lá offspring of Àlímì

Fúlàní of Sókótó origin

İṣọlá offspring of Álímì

Fúlàní of Sókótó origin)

People's identity can be determined by their self-conception as well as their social presentation; and how they behave within civilization. In the below example of song from Jáígbadé Àlàó, we see how the singer situates Súlú Adébímpé within the matter of national concern, the demise of the then President of Nigeria who was murdered. He presented Emir Súlú Adébímpé as the one who mourned the president. Let us examine what the artist said about the emir's reaction to the murdered president of Nigeria in his song.

Ó dodò oooooo

Ekún Múrítàlá dodò láyàà mi

Okọ àwa lọ

Múrítàlá tó lo túu táà ri kó dé mó

Olọ́hun ọ́fộrun kẹe

Nijọ Múrítàlá kú

Nò rí omi rí lóju Ọba ilú İlọin wa. 
Mo rómi lójú Súlú Adébímpé Oba wa tuntun tọ́ jẹ.

Lójú Émía wa t’ìlorin

Émíà sunkún títí d’Ógbómọṣọ

(It has turned into river

Muritala's mourning turned into river on my chest

Our benefactor has gone

Múrítàlá who left and we didn't see his return

May God forgive him

The day Múrítalá died

I have never seen the king of Îlọrin wept before

I saw tear on the face of Súlú Adébímpé, our newly installed king

On the face of our emir in İlọrin

The emir wept untill he arrived in Ògbómọ̣ṣọ)

Constructing identity figuratively involves metaphor and hyperbole or exaggeration. The artist above figuratively exaggerated the reaction of Emir Súlú Adébímpé to the death of Múrítàlá by saying that he wept profusely from İlọin until he got to Ògbómọ̣ọó, (a town that is about fifty miles from İlọin). This he did in order to present that the emir as humane and a considerate person. In the first two lines, the artist creates and constructs his personal identity as a concerned citizen of the society, especially in regards to the demise of the then Nigeria president.

Beside identity creation and historicity, the indigenous oral artists in İlọrin use their songs to reveal religious diffusion. As at today, the predominant religion in İlọin is Islam. However, it is discernible from the song of Àrẹmú Òsé that majority of the original inhabitants of the community before the advent of Islam were predominantly worshippers of the Yoruba traditional religion. In fact, up till today certain areas and neighborhoods in the city still bear names related to Yoruba deities, such as, Ọbàtálá, Șàngó, Mọlẹ, Yemọja, Ifá, Enlẹ and Òșun, among others:

Ėò tín bá n lọlé Olọjẹẹe 'Lọrin

Erò tín bá $n$ l'Olọojẹẹ Ilọin

E bá mi kí Aníbaba-lérí-odó

Ará Oníkasan

Àdisá Ògbín ọmọ Jàálà

Omọ Abinbólùgbọ́n

(Those going to Olộjẹẹ in İlọrin

Anyone going to Ọlọjẹ̣ẹ in İlọrin 
I send my greetings to Aníbaba-lérí-odó

A native of Oníkasan

Àdìsá Ògbín, the offspring of Jàálà

The offspring of Abínbólùgbọ́n)

The Olộjẹeé neighborhood is where the worship of Egúngún (Masquerade) was prominent before Alfa Alimi and his warriors defeated Àfọnjá and captured İlọin as part of Sókótó caliphate till today. The history of Îlọrin presents it as a Yorùbá town which was originally used as a military outpost by the Aláàfin, paramount ruler of the Old Ọyọ Empire (Ọyộ-Ilé). At the period of its creation, İlọrin was administered by Àfộnjá, the sixth Ààrẹ-Ọ̀nà-Kakaǹfo (generalissimo) of the Ọyọ́ army and successor of Ààrẹ-Ọ̀nà Oku of Jàbàtá. It was from this outpost that Àfọnjá carried out military functions for the then Aláàiin named Aólẹ, the son of Aláàfin Abíọ dún. Aólẹ reigned between 1789 and 1796. It was during this period that Shehu Alimi, a Fúlàní cleric, arrived İlorin with some of his tribesmen and were all welcomed and hosted by Àfọ̀njá.

After a while, conflict broke out between Aláàfin Aólẹ and Ààrẹ-Ọ̀nàKakaǹfò Àfọnjá. This made Àfọ̀njá sought the support of Shehu Alimi also known as Salih Janta who had both spiritual and military power. After defeating Aólẹ, Àfọnjá and Alimi's relationship strengthened to the extent that Àfọnjá enlisted Alimi's men into his army and disbanded many of his men whom history claimed he didn't fully trust. After Sheu Alimi's death, his son, Abdulsalam, earnestly yearned to rule İlọrin, and clandestinely plotted against Àfọ̀njá. After Àfợnjás death, Abdulsalam declared himself the Emir of İlọin and pledge allegiance to Sokoto Caliphate. This was how the monarch of İlọin holds the title of emir till today instead of the Yoruba title ọba.

Afterward, the Yorùbá attempted to regain control of İlọin from the Fúlàní but failed. Tóyèjẹ, the successor of À fọnjá, led the first and second attempts to drive the Fúlàní people out of İlorin. The second attempt is known in history as Mùgbámùgbá War in which Yorùbá people suffered untold defeat in the attempt to regain the throne of İlorin (Danmole et al, 1993, Johnson, S. 1921, Jamiu, 2014). This aspect of Ilorin history is aptly captured by Àrẹ̀múÒsé, showing that the forefathers of Sééhù Álímì migrated from Sokoto.

\section{Wòlii Dan Báwà}

Ààfáa Șééhù

İsọlá Òpó ọmọ Sùbéérù ní Sókótó

Àá tí n jọba nílùu 'Lơrin

Ojọ́ tọ́ pé ni

Irú Bùràimọ İsọ̣lá 
Irú rè è tíi je

İṣọlá ọmo Bùrẹẹmọ aráa Șókótó

İsọ̀lá Òpó

Omọ Àkáádi aráa Șókótó

Omo-ọmo Ayélabówó

Omo ọmo Sàídù Àlàó

Ọmọ Gògó Àlùkò

(Dan Báwà

Alfa Șééhù

İṣọlá Òpó child of Sùbéérù in Sókótó

The institution of kingship in İlorin town

Has been in existence for a long period

Somebody like Bùràímọ İṣọlá

Somebody like him has not been made king

İṣọlá Òpó child of Sùbéérù in Sókótó

İsọ̀lá Òpó

Child of Àkáádì native of Șókótó

Grandchild of Ayélabówó

Grandchild of Sàídù Àlàó

Child of Gògó Àlùkò)

It is really amazing the kind of identity that diffusion of culture created in İlorin as seen in the example of the song above. There is a combination of Yorùbá and Fúlàní names. For example, we have a combination of İsọ̀lá and Bùrẹẹẹọ from Sókótó. Also, İṣộlá, the child of Bùrẹẹemọ, bearing one of the totemic appellations of Yorùbá lineages, 'Òpó'. Social interaction and cultural diffusion have given room for the above kind of representation in the artist's song. Also, the king is referred to as the offspring of Bùrẹeẹmọ̀, Àkáádì, Ayélabówó, Sàídù Àlàó, and Gògó Àlùkò. There is a diffusion of Yorùbá and Islamic names. Another example of this is seen in the kèngbè song performed during a wedding ceremony of a princess thus:

Ọlọhun kó feríi jòkú wa

Súlú $n$ be lọ́run, bàbáa Kọlapò

Olộhun kó ferí jòku wa

Àlàbí $n$ be lọ́run, baba Làwepọ

Olọ́hun kó feríi jòku wa

(May God forgive the dead in heaven

Súlú, Kọ̀lapọ̀s father is in heaven 
May God forgive the dead in heaven

Àlàbí, Làwepọ̀s father is in heaven

May God forgive the dead in heaven)

The above excerpt refers to Súlú as the father of Kọlápọ̀. The singer also mentioned Àlàbí as the father of Láwépọ̀. Súlú is not a Yorùbá name, but through diffusion of culture and languages, the Fúlàní also bear names like Kọ́lápọ̀, Àlàbí Òpó, İṣọlá, and many others that are Yorùbá names.

\section{Conclusion}

From the foregoing, attempt has been made to study the contributions of indigenous singers in İlorin to the construction of social history and identity of the people in their locality. Identity construction is an integral part of human beings. In Yorùbá society, oral artists use the medium of oral performance to construct identity and social history of the society they are performing for. As we've shown in the essay, a substantial part of İlorin songs, chants, and recitals is devoted to eulogy because, according to Abubakre (2006:103), praise singing is part of the rich oral culture of the Yorùbá, who are the majority of the inhabitants of İlorin. This culture of praise forms a basic element of their public life. In addition to this, Islam, the religion professed by the people of İlorin, teaches that good deed should be acknowledged and appreciated.

\section{References}

Abubakre, R.D. (2006). "The leading Roles of Ilorin in Arabic Scholarship in Nigeria.” In: S. A. In Jimoh (ed.). Ilorin: Centre of Learning, Ilorin, Ilorin: University of Ilorin Press for Jimson Publishers, pp 99-111.

Ajíbádé, G.O. (2012). “The Yorùbá Oral Artists and Their Use of Words." Journal of Yoruba Studies Association of Nigeria 7(1):30-62.

Akinyemi, A. (2011). African oral tradition then and now: a culture in transition. Centrepoint Journal, Humanities Edition. 14(1): 27-51.

Barber Karin. (1979). "Oriki in Okuku: Relationships between Verbal and Social Structures." Unpublished Ph.D. dissertation, University of Ife, Nigeria. Ògúnșínà, B. (1987). "The sociology of the Yorùbá Novel: A Study of Isaac Thomas, D.O. Fágúnwà and Òkédijí.” Unpublished Ph.D., İbàdàn: University of İbàdàn.

Finnegan, Ruth. (1992). Oral Poetry: Its Nature, Significance and Social Context. Indiana University Press.

Okafor, R.C. (2015). Music in Nigerian Society. Enugu: New Generation Books. 
Danmole, H., T. Falola, \& S. Bada. (1993). “The Documentation of Ilorin by Samuel Ojo Bada." History in Africa, 20, 1-13. doi:10.2307/3171960.

Ibraheem, L. O. (2018). "The Contributions of İlọrin Scholars to Poetry in Arabic in Nigeria” Research Gate 17(2):129-144.

Jamiu, F.O. (2014). "Contributions of İlọin scholars to Arabic and Islamic studies in Yorùbá land: Focus on Shaykh Adam Abdullah Al-Iluri," African Journal of History and Culture 6(8):112-118. DOI: 10.5897/AJHC2014.0193 Johnson, S., (1921). The history of the Yorubas: From the earliest times to the beginning of the British protectorate. O. Johnson (Ed.). CMS, Lagos.

Salihu, H.A. \& Jawondo, I.A. (2006). "Ilorin Emirate: Its People and Politics." In S.A. Jimoh (ed.). Ilorin: Centre of Learning. Ilorin, JIMSON Publishers. 